\title{
THE RELATIONSHIP BETWEEN JOB STRESS AND WORKPLACE DEVIANT BEHAVIORS: A STUDY ON BANK EMPLOYEES IN BANGLADESH
}

\author{
Sabrin Sultana \\ Undergraduate Student \\ Banking \& Insurance Department \\ University of Chittagong, Bangladesh \\ E-mail: sabrinsultana1060@gmail.com \\ Athkia Subat \\ Undergraduate Student \\ Banking \& Insurance Department \\ University of Chittagong, Bangladesh \\ E-mail: subat.athkia@gmail.com \\ Md. Nasim Bhuiyan \\ Undergraduate Student \\ Banking \& Insurance Department \\ University of Chittagong, Bangladesh \\ E-mail: knasim938@gmail.com
}

\begin{abstract}
Despite the increasing number of studies on the relationship between job satisfaction and deviant behaviors in the workplace, still there is a lack of studies where job satisfaction has been measured considering stress and job engagement and also whether all of these three variables are directly correlated with workplace deviant behaviors or not. This study aims to investigate the relationship between job satisfaction and workplace deviant behaviors and other important objectives is the relationship between job satisfaction, stress, and job engagement with workplace deviant behaviors and the relationship between stress and job engagement with job satisfaction. Our study found that stress is liable for less satisfied employees which produces a high level of involvement in workplace deviant behaviors. On the other hand, job engagement creates job satisfaction which reduces workplace deviant behaviors. The quantitative approach is employed on 82 employees of private and public commercial banks. Based on PLS-SEM method conceptual frameworks were constructed, descriptive analysis and regression analysis were used. Our study concluded that there is a strong causal relationship between job stress, job engagement with job satisfaction which results in workplace deviant behavior. Therefore, workplace deviant behavior can be reduced if organizations take some recreational activities that will increase job engagement.
\end{abstract}

Keywords: Job Satisfaction, Workplace Deviant Behavior (WDB), Job Engagement, Stress, Bank Employees in Bangladesh. 


\section{INTRODUCTION}

Is job dissatisfaction liable for creating workplace deviant behaviors (WDB) in the organization? Stress and low job engagement are accountable for lower job satisfaction and higher WDB. We also measured job stress and job engagement of employees to find out whether these two variables influence job satisfaction and WDB. The output of an organization largely depends on the employees. So, if authority can ensure employees' satisfaction and also can ensure that employees' are not engage in deviant behaviors within theworkplace, organization would receive greater benefit in the long-run. (Bennett \& Robinson, 2000) has defined workplace deviance as voluntary behavior which violates various organizational norms and also threatens the well-being of employees or the organization. This type of behaviors such as aggression, theft, violence and absenteeism, etc. can be controlled by the various norms of organization (Feldman, 1984). According to Lawrence \& Robinson (2007) job satisfaction is very important because it has power and impact on both turnover and absenteeism. Job dissatisfaction has a link to workplace deviant behaviors. This linkage has been showed in a similar way by (Bowling, 2010). Employees tend to exhibit deviant behaviors with the purpose of releasing their emotional tensions when they are dissatisfied (Srivastava, 2012). From the previous studies, it can be said that employees who are dissatisfied may engage in workplace deviant behaviors such as sabotage of equipment, poor services and many destructive rumors. Bakker et al. (2002) defined the term engagement as a fulfilling, positive and work-related state of mind which is characterized by absorption, dedication and vigor.

Saks (2006) defined that job engagement can be related to job satisfaction positively. According to Appelbaum et al. (2005) a large number of profit loss and damaging atmospherein the organization are responsible for workplace deviant behaviors. Job stress is an emotional experience which is related with anxiety, strain, and tenseness and this originates from a job (Cooke \& Rousseau, 1984). Job stress and workplace deviant behaviors had a positive relationship and that result found after conducting a study on 162 employees in a public organization in Malaysia. (Omar et al., 2011). This study also revealed that employees who experienced irritation and frustration because of work related stress weremore prone to involve in deviant behaviors at the organization. Spector \& Fox (2005) defined that job stress and many other factors are accountable for deviant workplace behaviors. Some deviance behaviors are low productivity, absenteeism, lowjob motivation and alcoholism etc (Safaria et al., 2010). According to (Baum et al., 1981) stress is a kind of process in which different environmental forces or events, it can be termed as stressors, threaten an organism's existence as well as well-being.

This paper has been structured with abstract, keywords, problem statement, objective, literature review, methodology, result and findings, conclusion and future research direction. In Bangladesh, no study has been occurred on the relationship between job satisfaction and workplace deviant behaviors of bank employees considering stress and job engagement. Therefore, our objective is to showcase the relationship between job satisfaction and workplace deviant behaviors.

\section{OBJECTIVES OF THE RESEARCH}

- Exhibiting the relationship between workplace deviant behaviors and job satisfaction is the coreobjective of our study. In addition, some other objectives are:

- To show whether stress of the bank employees decreases job satisfaction and increases WDB in theorganization or not.

- To exhibit whether job engagement increases satisfaction of the employees and reduces WDB inthe organization or not. 


\section{LITERATURE REVIEW}

The main purpose of the chapter is to present a resume of conceptual frame work relating to application of regression analysis for deviant behaviors of employees of private and public banks in Bangladesh. Past studies gives way to future research endeavor. An acquaintance with earlier pertinent studies was felt necessary for better understanding of the research problem and to develop appropriate research methodology. The relevant studies and their findings are limited. However, an attempt is made to orient much on the theoretical views of different authors/scientists on the subject and closely related results are reported. Keeping in view the subject of the study, the review of the available literature related to the study are presented under the following discussion.

Job satisfaction can be defined as a person's feeling of satisfaction on his or her job, most importantly, it acts as a motivation to work. But job satisfaction is not the self-satisfaction or self-contentment, rather it is the satisfaction on the job. Job satisfaction eliminates various types of deviant behaviors, an intentional desire to cause harm to an organization, such as absenteeism, theft, acting rudely to co-workers etc. Stress negatively effects on deviant behaviors, whereas job engagement reduces deviant behaviors. Job engagement refers to the extent to which an employee feel very passionate about their jobs, specially they are committed to work, and put maximum effort into their tasks.

Greenberg and Scott (1996) investigated employee theft as a major form of organizational misbehavior. They claimed that these phenomenon are certainly universal and thus it is assumed that most members of the organizations engage in some form of misbehavior related to their jobs.

Mitchell and Ambrose (2007) carried out a research to examine the relationship between abusive supervision and employee workplace deviance using the moderating effects of negative reciprocity beliefs. They hypothesized that negative reciprocity will moderate the relationship between abusive supervision and employee deviance; also abusive supervision will be strongly associated to supervisor-directed deviance when employees believe in negative reciprocity. They found that abusive supervision is positively and significantly related to each type of deviance. Further, negative reciprocity beliefs were significantly and positively related to all types of deviance. They concluded that employees with negative reciprocity beliefs consider revenge an appropriate response to negative treatment.

A study carried out by Chen and Spector (1992) included measures of role ambiguity, role conflict, interpersonal conflict and workload along with organizational constraints in relation to work place deviance. They showed a support for the link between stress and deviance. They also examined work stressors, aggression, theft and substance abuse. The result showed all of them were correlated significantly with hostility and all but workload were correlated significantly with aggression and sabotage.

A meta-analysis of 57 empirical studies regarding workplace aggression's antecedents was conducted by Hershcovis et al. (2007). Findings of the studies showed certain predictors of deviant behavior in the workplace. Specially, interpersonal conflict was highlighted as a predictor of deviance. Deviance was found to be a method coping with workplace stressors. The results of this research indicated that the strongest predictors of deviant behavior in the workplace were interpersonal conflict and situational constraints.

Mount et al. (2006) posits that individual-related factors (i.e. agreeableness and conscientiousness) are related to workplace deviant behavior through the mediating effect of job satisfaction. In terms of practice, the results of this study add to the body of knowledge on 
workplace deviant behavior from the Malaysian public service context and HRD practices.

Workplace deviant behavior may be regarded as a negative reciprocity orientation where an individual returns a negative treatment with a negative treatment (Mitchell \& Ambrose, 2007). Lawrence and Robinson (2007) found that the increasing pressure in organizations as a result of increasing competition and economic challenges that may call for restructuring and downsizing may result into employees' misconductin organizations.

\section{Research Design}

\section{METHODOLOGY}

The study used experimental quantitative research design along with a set of questionnaire. The study is designed to find out the causal relationship of job satisfaction, job stress, job engagement compare to the workplace deviant behavior. Exploratory research is conducted to determine the causal relationship of dependent and independent variable.

\section{Participants and Procedures}

This study is conducted on the bank employee of several private and public commercial banks of Bangladesh. A total of 82 participants of the study was randomly selected from those organizations.

\section{Hypotheses}

This study is designed with four variables namely Job satisfaction, Job engagement, Job Stress and WDB.The study is based on following hypotheses.

H1: $_{1}$ There is positive relation between Job Engagement and Job Satisfaction.

H2: There is negative relation between Job Stress and Job Satisfaction.

H3: There is negative relation between Job Engagement and WDB.

H4: There is positive relation between Job Stress and WDB.

H5: There is negative relation between Job Satisfaction and Workplace Deviant Behavior.

\section{Questionnaire Design}

We used a questionnaire consists of five sections; demographic data, job engagement, stress, job satisfaction, and workplace deviant behaviors. (Vance, 2006), (Alpern et al., 2013), (Bennett \& Robinson, 2000)

\begin{tabular}{l}
$\begin{array}{l}\text { S_1: I feel mental stress because of too much } \\
\text { work. S_2: I am seldom rewarded for my hard } \\
\text { work and efficient performance. }\end{array}$ \\
$\begin{array}{l}\text { S_3: My authorities do not give few I I am satisfied with the bank's promotion } \\
\text { significance tomy post and work. }\end{array}$ \\
$\begin{array}{l}\text { policy. } \\
\text { ST_2: The employees in my branch have good } \\
\text { relationships among each other. } \\
\text { ST_3: My supervisor is fair and he evaluates } \\
\text { job performance based on clear performance } \\
\text { standard.ST_4: This Bank's management is of } \\
\text { best standards. }\end{array}$ \\
\hline
\end{tabular}




E_1: I take the initiative to help other W_1: I embarrassed someone publicly at work.
employeeswhen problem arises,
E_2: I accept changes in the Bank willingly,
E_3: I am always willing to take tasks.
W_2: I spend too much time on fantasizing
W_3: I usually put little effort into my work.
W_4: I have taken things from bank without
permission.
W_5: Sometimes i intentionally worked at a
slowerpace than my capacity.

\section{Demographic Survey and Statistical Tools}

The study is employed using Microsoft Excel, IBM SPSS 20 and Smart PLS 3. This study mainly followed Structured Equation Modeling to describe the causality of the dependent and independent variables.

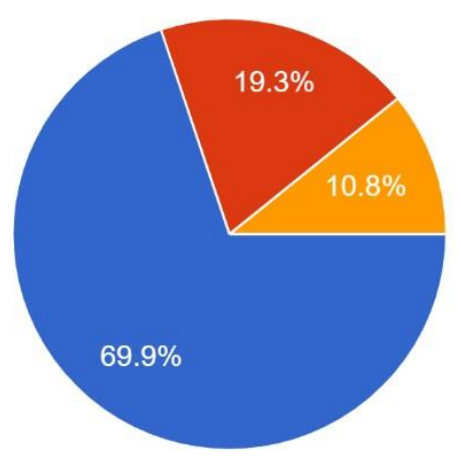

Prefer not to say

Figure 1. Gender

In the following study, out of 82 participants, $70 \%$ are male and $19.3 \%$ are female. Also, $10.8 \%$ participantdidn't respond to the respective question and most of the participants were having 1 to 10 years of job experience in their current organizations.

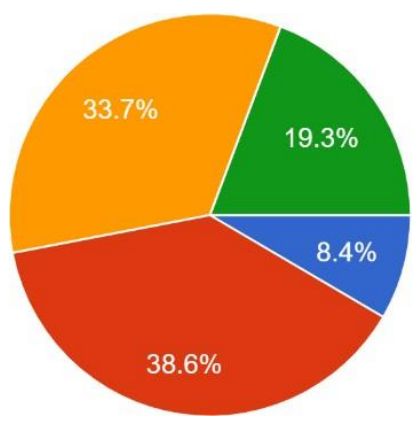

Less than 1 year

1 year -5 years

5 years -10 years

More than 10 years

Figure 2. Work Experience. 


\section{Conceptual Framework}

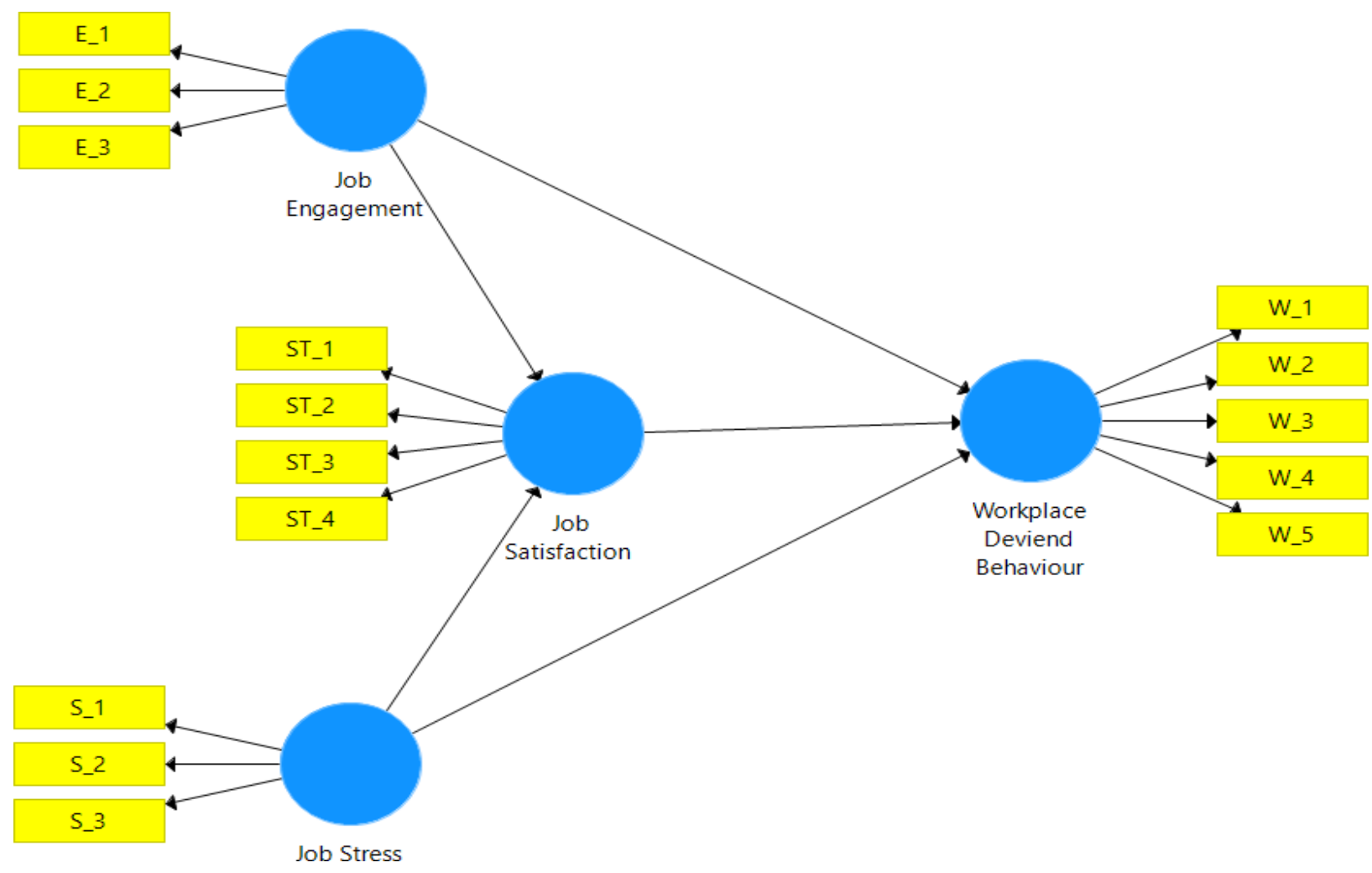

Figure 3. Conceptual Framework

This model is employed using Structured Equation Modeling approach. In order to define causal effect this model is constructed considering workplace deviant behavior and job satisfaction as dependent variable.

Figure 3 shows that job stress and job engagement might have a causal effect with job satisfaction and workplace deviant behavior. It means that if any employee have comparatively higher job stress, he/she might be dissatisfied with the job which will result in workplace deviant behaviors.

On the other hand, the employees who more or less behave positively with the given tasks and highly engaged with the organizational activities, might be satisfied with their job and ultimately will not show theworkplace deviant behaviors.

\section{RESULT AND DISCUSSION}

Table 1. Descriptive Statistics

\begin{tabular}{|l|c|c|c|c|c|c|c|c|c|}
\hline & $\mathrm{N}$ & Minimum & Maximum & Mean & $\begin{array}{c}\text { Std. } \\
\text { Deviation }\end{array}$ & \multicolumn{2}{|c|}{ Skewness } & \multicolumn{2}{|c|}{ Kurtosis } \\
\cline { 2 - 10 } & Statistic & Statistic & Statistic & Statistic & Statistic & Statistic & $\begin{array}{c}\text { Std. } \\
\text { Error }\end{array}$ & Statistic & $\begin{array}{c}\text { Std. } \\
\text { Error }\end{array}$ \\
\hline Engagement & 82 & 3.00 & 13.00 & 8.3902 & 2.10089 & -.067 & .266 & -.192 & .526 \\
\hline
\end{tabular}




\begin{tabular}{|c|c|c|c|c|c|c|c|c|c|}
\hline Stress & 82 & 5.00 & 19.00 & 11.8171 & 3.31896 & -.174 & .266 & -.424 & .526 \\
\hline WDB & 82 & 5.00 & 19.00 & 11.8171 & 3.31896 & -.174 & .266 & -.424 & .526 \\
\hline Satisfaction & 82 & 8.00 & 20.00 & 14.7073 & 3.01637 & -.423 & .266 & -.517 & .526 \\
\hline $\begin{array}{c}\text { Valid N (List } \\
\text { wise) }\end{array}$ & 82 & & & & & & & & \\
\hline
\end{tabular}

\section{Source: SPSS Output}

Table 1 shows the descriptive statistics for the dependent and independent variables. It describes the highest mean value for the job satisfaction and lower mean value for the job engagement. Considering the items of the variables the mean value depicts that bank employees are satisfied with overall workplace environment. Also, Standard Deviation of the statistics shows highest for the variable WDB and Stress which means employees are more or less habituated with work stress and which result in negative behavioral attitude. The standard value of skewness and kurtosis is in between +2 and -2 . In this study, the skewness and Kurtosis value concludes that data is normally distributed.

Table 2. Correlations

\begin{tabular}{|c|c|c|c|c|}
\hline & WDB & Engagement & Stress & Satisfaction \\
\hline WDB & 1.000 & -.140 & 1.000 & -.348 \\
\hline Engagement & -.140 & 1.000 & .140 & .330 \\
\hline \multicolumn{5}{|c|}{ Pearson Correlation } \\
\hline Stress & 1.000 & -.140 & 1.000 & -.348 \\
\hline Satisfaction & -.348 & .330 & -.348 & 1.000 \\
\hline WDB & . & .105 & .000 & .001 \\
\hline Engagement & .105 & . & .105 & .001 \\
\hline \multicolumn{5}{|c|}{ Sig. (1-tailed) } \\
\hline Stress & .000 & .105 & . & .001 \\
\hline Satisfaction & .001 & .001 & .001 & . \\
\hline WDB & 82 & 82 & 82 & 82 \\
\hline Engagement & 82 & 82 & 82 & 82 \\
\hline \multicolumn{5}{|l|}{$\mathrm{N}$} \\
\hline Stress & 82 & 82 & 82 & 82 \\
\hline Satisfaction & 82 & 82 & 82 & 82 \\
\hline
\end{tabular}

\section{Source: SPSS Output}

Table two shows the Pearson correlation matrix for the dependent and independent variables. It describes that Job Stress is significantly correlated with WDB. It concludes that stress is the significant reason for showing dissatisfaction and deviant behaviors in their 
workplace. This table also concludes that unsatisfied employees significantly show the workplace deviant behavior. Moreover, it is also found that there is significant positive correlation between job engagement and job satisfaction.

Table 3. Reliability Matrix

\begin{tabular}{|l|l|l|l|l|}
\hline Variables & $\begin{array}{l}\text { Cronbach's } \\
\text { Alpha }\end{array}$ & rho A & $\begin{array}{l}\text { Composite } \\
\text { Reliability }\end{array}$ & $\begin{array}{l}\text { Average Variance } \\
\text { Extracted (AVE) }\end{array}$ \\
\hline Job Engagement & 0.692 & 0.59 & 0.385 & 0.281 \\
\hline Job Satisfaction & 0.821 & 0.826 & 0.818 & 0.532 \\
\hline Job Stress & 0.464 & 0.619 & 0.543 & 0.306 \\
\hline WDB & 0.666 & 0.683 & 0.655 & 0.285 \\
\hline
\end{tabular}

Source: Smart PLS 3 output

Reliability matrix shows the internal consistency of the items. Cronbach's Alpha value concludes that the variable job satisfaction $(>.80)$ is consistent according to its value. The Alpha value of job engagement, job stress and workplace deveined behavior is less than .8 which is inconsistent.

Table 4. Regression

\begin{tabular}{|l|l|l|}
\hline & R Square & R Square Adjusted \\
\hline Job Satisfaction & 0.288 & 0.27 \\
\hline WDB & 0.397 & 0.374 \\
\hline
\end{tabular}

Source: Smart PLS 3 output

R Square value describes the internal variability of the proposed model. Table 4, workplace deviant behavior describes $39.7 \%$ variability of the model whereas Job Satisfaction defines $28.8 \%$ variability of themodel.

Table 5. Outer weight of items

\begin{tabular}{|c|c|c|c|c|c|}
\hline Outer weight & $\begin{array}{l}\text { Original } \\
\text { Sample } \\
(0)\end{array}$ & $\begin{array}{l}\text { Sample } \\
\text { Mean(M) }\end{array}$ & $\begin{array}{l}\text { Standard } \\
\text { Deviation } \\
\text { (STDEV) }\end{array}$ & $\begin{array}{l}\text { T Statistics } \\
(\mid \text { O/STDEV } \mid)\end{array}$ & P Values \\
\hline \multicolumn{2}{|c|}{ E_1 <- engagement 0.606} & 0.502 & 0.269 & 2.249 & 0.025 \\
\hline E_2<- engagen & $\mathrm{t}-0.102$ & 0.018 & 0.405 & 0.253 & 0.8 \\
\hline E_3<- engagen & $\mathrm{t} 0.561$ & 0.474 & 0.218 & 2.577 & 0.01 \\
\hline $\begin{array}{l}\text { ST_1 <- } \\
\text { satisfaction }\end{array}$ & 0.32 & 0.321 & 0.05 & 6.339 & 0 \\
\hline $\begin{array}{l}\text { ST_2 <- } \\
\text { satisfaction_ }\end{array}$ & 0.255 & 0.259 & 0.054 & 4.714 & 0 \\
\hline $\begin{array}{l}\text { ST_3 <- } \\
\text { satisfaction }\end{array}$ & 0.346 & 0.343 & 0.042 & 8.204 & 0 \\
\hline
\end{tabular}




\begin{tabular}{|l|l|l|l|l|l|}
\hline $\begin{array}{l}\text { ST_4<- } \\
\text { satisfaction_ }\end{array}$ & 0.318 & 0.314 & 0.064 & 5.003 & 0 \\
\hline S_1 <- stress & 0.302 & 0.274 & 0.221 & 1.365 & 0.173 \\
\hline S_2 <- stress & 0.396 & 0.377 & 0.187 & 2.125 & 0.034 \\
\hline S_3 <- stress & 0.654 & 0.625 & 0.138 & 4.722 & 0 \\
\hline W_1<- WDB_ & 0.221 & 0.223 & 0.124 & 1.785 & 0.075 \\
\hline W_2<- WDB_ & 0.228 & 0.245 & 0.108 & 2.107 & 0.035 \\
\hline W_3<- WDB_ & 0.32 & 0.308 & 0.121 & 2.636 & 0.009 \\
\hline W_4<- WDB_ & 0.393 & 0.349 & 0.093 & 4.202 & 0 \\
\hline W_5<- WDB_ & 0.348 & 0.334 & 0.108 & 3.215 & 0.001 \\
\hline
\end{tabular}

Source: Smart PLS 3 output

Table 5 shows outer weights for each item of the variable. Outer weights of the following model show thatall the items of the variables are statistically significant $(<0.05)$ except the $\mathrm{S} 1$ for job stress and W1 for WDB.

Table 6. Decision Table

\begin{tabular}{|c|l|l|}
\hline Hypothesis & \multicolumn{1}{|c|}{ Description } & Decision \\
\hline $\mathbf{H}_{\mathbf{1}}$ & $\begin{array}{l}\text { There is positive relation between Job } \\
\text { Engagement and Job Satisfaction }\end{array}$ & Accepted \\
\hline $\mathbf{H}_{\mathbf{2}}$ & $\begin{array}{l}\text { There is negative relation between Job Stress and } \\
\text { Job Satisfaction }\end{array}$ & Accepted \\
\hline $\mathbf{H}_{\mathbf{3}}$ & $\begin{array}{l}\text { There is negative relation between Job } \\
\text { Engagement and WDB. }\end{array}$ & Accepted \\
\hline $\mathbf{H}_{\mathbf{4}}$ & $\begin{array}{l}\text { There is positive relation between Job Stress and } \\
\text { WDB. }\end{array}$ & Accepted \\
\hline $\mathbf{H}_{\mathbf{5}}$ & $\begin{array}{l}\text { There is negative relation between Job } \\
\text { Satisfaction and WDB. }\end{array}$ & Accepted \\
\hline
\end{tabular}

\section{CONCLUSION}

To conclude, this study found that job satisfaction, stress and job engagement were correlated with WDB. Besides, stress and job engagement had correlation with job satisfaction. However, the direction of the correlation of variables were not same. The more job engagement and satisfied employees in the organization, the lesser the WDB. While for stress the more stress employees experience, the higher the WDB. In another model, we showed that job engagement and stress had positive and negative correlation with job satisfaction respectively. Organization and the authority must ensure employees' job satisfaction and should pay attention to the reasons for job stress and low job engagement which will lessen WDB.

For future research on this similar study, the number of respondents should be extended. Furthermore, more research is highly needed by specifying and considering organization's internal and external factors associated with job satisfaction, job stress, job engagement and WDB. 


\section{REFERENCES}

Alpern, R., Canavan, M. E., Thompson, J. T., McNatt, Z., Tatek, D., Lindfield, T., \& Bradley, E. H. (2013). Development of a brief instrument for assessing healthcare employee satisfaction in a low-income setting. PLoS ONE, 8(11). https://doi.org/10.1371/journal.pone.0079053

Appelbaum, S. H., Deguire, K. J., \& Lay, M. (2005). The relationship of ethical climate to deviant workplace behaviour. Corporate Governance, 5(4), 43-55. https://doi.org/10.1108/14720700510616587

Bakker, A., Gonzáles-Romá, V., Salanova, M., \& Schaufeli, W. (2002). The measurement of Engagement and Burnout: A Two Sample confirmatory factor analytic approach. Journal of Happiness Studies, 3(1), 71-92. Retrieved from http://www.jwalkonline.org/docs/Grad Classes/Fall 07/Org Develop/presentation/ARTICLES/measure engage and burnout.pdf

Baum, A., Singer, J. E., \& Baum, C. S. (1981). Stress and the Environment., 37(1), 4-35. https://doi.org/https://doi.org/10.1111/j.1540-4560.1981.tb01056.x

Bennett, R. J., \& Robinson, S. L. (2000). Development of a measure of workplace deviance. Journal of Applied Psychology, 85(3), 349-360. https://doi.org/10.1037//00219010.85.3.349

Bowling, N. A. (2010). Effects of job satisfaction and conscientiousness on extra-role behaviors. Journal of Business and Psychology, 25(1), 119-130. https://doi.org/10.1007/s10869009-9134-0

Chen, P. Y., \& Spector, P. E. (1992). Relationships of work stressors with aggression, withdrawal, theft and substance use: An exploratory study. Journal of Occupational and Organizational Psychology, 65(3), 177-184. https://doi.org/10.1111/j.20448325.1992.tb00495.x

Cooke, R. A., \& Rousseau, D. M. (1984). Stress and strain from family roles and work-role expectations. Journal of Applied Psychology, 69(2), 252-260. https://doi.org/10.1037/0021-9010.69.2.252

Feldman, D. C. (1984). The Development and Enforcement of Group Norms. Academy of Management Review, 9(1), 47-53. https://doi.org/10.5465/amr.1984.4277934

Greenberg, J., \& Scott, K. S. (1996). Why do workers bite the hands that feed them? Employee theft as a social exchange process. Research in Organizational Behavior, 18(c), 111156.

Hershcovis, M. S., Turner, N., Barling, J., Arnold, K. A., Dupré, K. E., Inness, M., ... Sivanathan, N. (2007). Predicting workplace aggression: A meta-analysis. Journal of Applied Psychology, 92(1), 228-238. https://doi.org/10.1037/0021-9010.92.1.228 
Lawrence, T. B., \& Robinson, S. L. (2007). Ain't Misbehavin: Workplace deviance as organizational resistance. Journal of Management, 33(3), 378-394. https://doi.org/10.1177/0149206307300816

Mitchell, M. S., \& Ambrose, M. L. (2007). Abusive Supervision and Workplace Deviance and the Moderating Effects of Negative Reciprocity Beliefs. Journal of Applied Psychology, 92(4), 1159- 1168. https://doi.org/10.1037/0021-9010.92.4.1159

Mount, M., Ilies, R., \& Johnson, E. (2006). Relationship of personality traits and counterproductive work behaviors: The mediating effects of job satisfaction. Personnel Psychology, 59(3), 591-622. https://doi.org/10.1111/j.1744-6570.2006.00048.x

Omar, F., Halim, F. W., Zainah, A. Z., Farhadi, H., Nasir, R., \& Khairudin, R. (2011). Stress and job satisfaction as antecedents of workplace deviant behavior. World Applied Sciences Journal, 12(16), 45-51.

Safaria, T., Othman, A. bin, \& Abdul Wahab, M. N. (2010). Religious Coping, Job Insecurity and Job Stress among Javanese Academic Staff: a Moderated Regression Analysis. International Journal of Psychological Studies, 2(2). https://doi.org/10.5539/ijps.v2n2p159

Saks, A. M. (2006). Antecedents and consequences of employee engagement. Journal of $\begin{array}{lll}\text { Managerial Psychology, 21(7), } & \text { 600-619. }\end{array}$ https://doi.org/https://doi.org/10.1108/02683940610690169

Spector, P. E., \& Fox, S. (2005). The Stressor-Emotion Model of Counterproductive Work Behavior. American Psychological Association, 151-174. https://doi.org/https://doi.org/10.1037/10893-007

Srivastava, S. (2012). Workplace Passion as a Moderator for Workplace Deviant Behaviour-Job Satisfaction Relationship: A Comparative Study between Public Sector and Private Sector Managers. Asia-Pacific Journal of Management Research and Innovation, 8(4), 517-523. https://doi.org/10.1177/2319510x13481914

Vance, R. J. (2006). Employee engagement and commitment: A guide to understanding, measuring and increasing engagement in your organization. SHRM Foundation's Effective Practice Guidelines, 1-53.

\section{Copyrights}

Copyright for this article is retained by the author(s), with first publication rights granted to the journal. This is an open-access article distributed under the terms and conditions of the Creative Commons Attribution license (http://creativecommons.org/licenses/by/4.0) 